
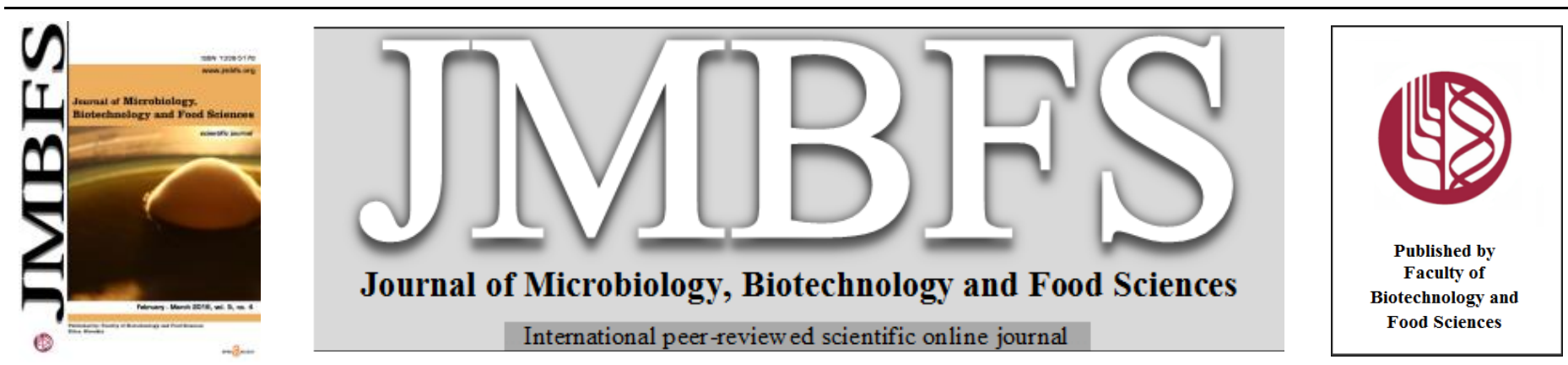

\title{
AMINO ACID PROFILING OF YEAST CREAM; A POTENTIAL PROTEIN ENRICHED INGREDIENT FOR POULTRY FEED
}

\section{Zafar Iqbal $^{1^{*}}$, Zahid Anwar $^{2,3^{*}}$, Muddassar Zafar ${ }^{3}$, Shoaib Ali ${ }^{4}$, Muhmmad Khurshid ${ }^{1}$, Munir Ahmad Sheikh ${ }^{4}$, Muhammad Irshad $^{3}$}

\section{$\operatorname{Address}(e s)$ :}

${ }^{1}$ Institute of Biochemistry and Biotechnology, University of the Punjab, Lahore, Pakistan.

${ }^{2}$ Department of Biochemistry, Nawaz Sharif Medical College, University of Gujrat, Pakistan.

${ }^{3}$ Department of Biochemistry and Molecular Biology, University of Gujrat, Pakistan.

${ }^{4}$ Department of Chemistry, University of Agriculture, Faisalabad, Pakistan.

*Corresponding author: Zahid.anwar20@gmail.com

doi: 10.15414/jmbfs.2016.5.4.369-373

\section{ARTICLE INFO}

Received 2. 4. 2015

Revised 21. 9. 2015

Accepted 25. 11.2015

Published 1. 2. 2016

\section{Regular article}

open ${ }_{\text {ACCESS }}$

\begin{abstract}
Yeast cream, an extremely good source of single cell protein (SCP), is formed as a by-product after the fermentation of molasses by Saccharomyces cerevisiae in bioethanol industry. A huge amount of yeast cream is produced annualy but seldom has destined as protein source in food industry therefore, produced yeast cream, is discarded due to no utilization especially in under developed countries including Pakistan. The yeast cream can be utilized in various food and feed industries (espcially in poultry industry) in a promising way to solve the protein shortage problems. Although, in previous century, several attempts have been under taken at larger scale to opt SCP as a potential human food ingredient to combat the protein shortage but failed due to its potential hazardous ingredients. However, adopting SCP as a potential poultry feed ingredient can potentially alleviate the such effects. This current study was aimed at deciphering the amino acid level in yeast cream in order to investigate its potential usage in poultry industry . To meet the objectives, three different independent yeast cream samples of two different strains of Saccharomyces cerevisiae Instant saf and Thermophilic yeast (Red) were collected from Shakarganj sugar mills distillery, Jhang and their amino acids profiling was determined with the help of HPLC. Our results pinpointed that yeast cream produced by Thermophilic yeast (Red) contains optimal level of essential amino acids. Thus, we hereby recommend that yeast cream produced by Thermophilic yeast (Red) can potentially be employed, as a protein source, in poultry feed. However, careful and sophisticated experimentation is required before adopting yeast cream as a protein substitute in poultry feed.
\end{abstract}

Keywords: yeast cream, Single cell protein, Sacchromycescerevisiae, HPLC, poultry feed

\section{INTRODUCTION}

Yeast are unicellular eukaryotes belonging to phylogenetic group of fungi and classified into two groups Ascomycetous and Basidiomycetous (Gadanho et al., 2003). Yeasts are extensively exploited for production of alcoholic beverages, leaven bread dough, enhance or impart a meaty flavour to food products, preparation of soups, gravies, meat products, sauces and in the flavouring of snacks (Stewart et al., 1998; Walker et al., 1998; Erten \& Tanguler., 2006). Sacchromyces cerevisiae, a specie of yeast, is a cheaper source and have been very instrumental in baking, winemaking and brewing since very very long ago (Stam, 1998). As a result of fermentation of molasses, a huge amount of yeast cream is produced every year. About $\sim 1300$ tons dry matter (DM) of distillery yeast biomass is disposed of annually (Khan, 2001). It is considered as a toxic waste and its disposal creat environmental problems due to its some polluting characteristics (Bustamante, 2008). Proximate analysis indicated that yeast cream contains 27 to $29 \%$ crude protein that could be utilized as a single cell protein (SCP) for poultry and feed stock for fish diets (Sharif, 2012).

Poultry industry is highly dynamic and progressive industry that is expanding with every passing day, it has became a leading protein source for human beings. However, continuous supply of chicken is directly linked to uninterrupted supply of broiler's feed - especially its ingredients. Protein requirements vary according to animal need, for example, poultry broiler chicks need more protein as compared to layers i.e. White Leghorn chicks. Among chief broilers feed ingredients, the (essential) amino acids are of chief importance for chicks development. Various independent studies have unraveled the importance of amino acids in chicken development. U.S. Organic poultry companies concluded that low amount of metheionine in fast growing birds can reduce immune response, poor feathering, cannibalism and feather pecking and increase mortality (Anne 2008). Diet of birds enriched with sulphur containing amino acids (metheionine and cysteine) can increase the antitoxicity which can prevent damage to cells by combating with free radicals (Anonymous, 2009) and thus boost defense against invading pathogens (Diz, 2006). Although, in the current scenario, soyabean is being used widely in poultry industry but studies have shown that the relative amount of methionine and cystine is quite low that making it unideal to use in poultry industry. These two amino acids, methionine and cysteine respectively, are major limiting amino acid for birds (Baize, 2000). To meet the protein demands of broiler's feed industry, different sources including plants, whey, fish meal and feather meal were exploited. However, limitations were observed for example cereals contain only $12-15 \%$ protein while, $15-20 \%$ of protein is required for growing chicks, additionally, this source is deficient in essential amino acids like methionine and/or lysine.Synthetic herbal products (likeAV/CAP/18) enriched with methionine, choline, lysine and biotin are used in broiler feed which have capability of feed additive as well as hepatoprotective (Kanuri, 2014). Fishmeal, another protnecious source, is relatively deficient in methionine, lysine, histidine, and tryptophan as compared to other source of protein. Feather meal has high content of cysteine, which can inhibit the uptake of both D- and L-methionine in the chick mucosal epithelial membrane (Saima, 2008).

Previous studies have shown that addition of organc acids in poultry feed can effectively increase the absorption of vitamins $\mathrm{D}$ and $\mathrm{K}$ in chickens, and helps in the formation of soluble salts of calcium and iron (Teresa, 2009). Fresh acid whey mixed with a poor-quality feed effectively declined the mortality rate due to the high amount of amino acids like methionine, lysine and tryptophan. All aforementioned amino acids are, present in high amount in the yeast cream as compared to cereals and these are essential for the growth and health of the animals (Sudha, 2005).

The poultry industry is gaining an importance in developing countries like Pakistan with an annual growth rate about 8 to $10 \%$ (Economic Survey of Pakistan, 2013-2014). On the other side, increasing human population have generated the competition between human beings and poultry for feed. 
Ultimately the price and scarcity of feedstock create poor performance of poultry industry. It is estimated that poultry feed accounts for $65-75 \%$ of total production cost (Esonu, 2006). This has forced the scientist to explore alternate source of protein, especially economical and those one where human are not directly competeing for food with animals. Keeping in mind of such conditions, we investigated the useability of yeast cream, which is by product of distillation process and have no commercial and economical values in Pakistan, as a raw source of protein to replace other sources on which human are directly dependent. To best of our knowledge, no study is available in Pakistan that focus on use of yeast cream as a potential source of amino acids. The study describes here examined with a motive to unravel the nutritional importance of yeast cream in poultry industry. In this purposed study, amino acid profiling along with presence of lactic acid was assessed for commercial use of yeast cream in poultry feed.

\section{MATERIALS AND METHODS}

\section{Sample collection and defatting of samples}

Batch samples of yeast cream from three independent fermenters were collected carefully from the Shakarganj Sugar Mills Distillery, Jhang, Pakistan. Yeast cream samples produced from commonly used yeast (Saf Instant) was named "S", while yeast cream samples produced by thermophilic yeast (Red Alcohol) were labeled with " $T$ ". Collected samples were dried in oven at $60^{\circ} \mathrm{C}$ for 2 days The samples were defatted by Soxhelt's apparatus (Pyrex 3740-S, USA) at the Department of Animal Nutrition, University of Agriculture, Faisalabad. To dafa the samples, a known weight of dried sample was extracted with petroleum ether (40 to $60^{\circ} \mathrm{C}$ ) in Soxhlet's apparatus. The extracted material was collected in a petridish and oven dried at $60^{\circ} \mathrm{C}$. Samples were stored and used for HPLC analysis.

\section{Crude protein and nitrogen estimation}

Crude protein and percentage of nitrogen was estimated with the help of Kjeldahl's apparatus as described by A.O.A.C, 1990 at Central Hi-Tech Laboratory, University of Agriculture, Faisalabad. A known weight of dried sample was digested in Kjeldahl flask with $30 \mathrm{~mL}$ of concentrated sulfuric acid and $5 \mathrm{~g}$ of digestion mixture $\left(\mathrm{CuSO}_{4} 0.5 \mathrm{~g}, \mathrm{FeSO}_{4} 0.5 \mathrm{~g}, \mathrm{~K}_{2} \mathrm{SO}_{4} 0.5 \mathrm{~g}\right.$ and $25 \mathrm{~mL}$ $\mathrm{H}_{2} \mathrm{SO}_{4} / 100 \mathrm{~mL}$ ). The contents of the flask were heated until light green or clear solution was obtained. The digested material was diluted in a $250 \mathrm{~mL}$ volumetric flask. $10 \mathrm{~mL}$ of diluted and digested sample solution was transferred into micro Kjeldahl distillation apparatus along with concentrated solution of $\mathrm{NaOH}(40 \%)$ Ammonia was diluted into $10 \mathrm{~mL}$ of Boric acid $(2 \%)$ solution containing a few drops of methyl red indicator.The distillate was titrated against N/10 sulphuric acid to light pink colour end point. From the volume of N/10 sulphuric acid, percent nitrogen was calculated by using the following formula:

$\%$ Nitrogen $=$ Volume of N/10 sulphuric acid used $\times .0014 \times 250 \times 100$ Volume of diluted solution $\mathrm{x}$ weight of sample
The percentage of crude protein was worked out by using the following formula $\%$ Crude Protein $=\%$ Nitrogen $\times 6.25$

\section{Sample preparation for HPLC analysis}

To determine the amino acid profile through High Pressure Liquid chromatography (HPLC, Model 10A, Schimadzu, Japan). To hydrolyze the protein into amino acid $70 \mathrm{mg}$ of dried yeast cream was pored into test tube then dissolved in $5 \mathrm{~mL}$ of $6 \mathrm{~N} \mathrm{HCl}$ and Nitrogen gas was passed through all the samples under vacuum to remove the excess $\mathrm{HCl}$. Test tubes were sealed using a flame produced by a mixture of different gases. Samples were placed in the oven at $110^{\circ} \mathrm{C}$ for a period of 22 hours. All the samples were cooled to room temperature and test tubes containing the samples were broken from the top. Treated samples of yeast cream were transferred to the China dishes, oven dried at $60^{\circ} \mathrm{C}$ and mixed thoroughly with $3 \mathrm{~mL}$ of $0.02 \mathrm{~N} \mathrm{HCl}$. Samples were then centrifuged at 10,000rpm for 15 minutes ( $\mathrm{min}$ ) and supernatant containing amino acids were separated for final HPLC analysis.

\section{HPLC analysis for amino acid estimation}

The concentration of amino acids were assessed in yeast cream samples through HPLC after modifying the method described by Skotty and co-worker (Skotty et al, 1996). The amino acid profiling in yeast cream samples were determined at temperature $30^{\circ} \mathrm{C}$ by using nonpolar or reversed phase C-18 Octadecyl Silicate (ODS) column having $15 \mathrm{~cm}$ length, $4.6 \mathrm{mM}$ diameter and particle size of $5 \mu \mathrm{M}$ Solvent triflouroacetic acid $(0.1 \%)$ and acetonitrile $(99.9 \%)$ used as a mobile phase with different mixing ratio using a gradient mode of HPLC and flow rate maintained at $1 \mathrm{~mL} / \mathrm{min}$. The amino acids were detected using spectral detector (SPD-10AV, Schimadzu) at a $280 \mathrm{~nm}$ wavelength. The amino acids peaks were acquired using CSW32 software and were calculated on amino acid calibration standards. The results of different samples of yeast cream were compared with standards of amino acids for both quantitative and qualitative analysis (Table 1). Retention time and peak areas of standards were noted and calculated respectively. These calculations were employed for estimation of amounts of different amino acids present in the samples of yeast cream. A whole set of experiments was repeated thrice.

\section{RESULTS}

\section{Optimization of amino acid standards}

All the aforesaid HPLC conditions were used to check the concentration/separation of standards amino acids and found to be satisfactory. Every standard was run in equal concentration $(100 \mu \mathrm{g} / \mathrm{mL})$ and all the parameters (including retention time, peak area and peak height) were determined. These resuts pinpointed that the first amino acid, iso-leucine, was eluted at 2.33 minutes while last amino acid, glutamine, was eluted at 37.50 minutes run time (Table 1).

Table 1 Chromatographic calculations of amino acids (standards)

\begin{tabular}{|c|c|c|c|c|c|c|c|}
\hline Sr.\# & Amino acid & $\begin{array}{c}\text { Concentration } \\
(\mu \mathrm{g} / \mathrm{mL})\end{array}$ & $\begin{array}{c}\text { Retention } \\
\text { Time (min) }\end{array}$ & $\begin{array}{c}\text { Peak Area } \\
(\mathrm{mV} . \mathbf{s})\end{array}$ & $\begin{array}{c}\text { Peak Area } \\
(\%)\end{array}$ & $\begin{array}{c}\text { Peak } \\
\text { Height } \\
(\mathrm{mV})\end{array}$ & $\begin{array}{c}\text { Peak } \\
\text { Height } \\
(\%)\end{array}$ \\
\hline 1 & Phenylalanine & 100 & 3.10 & 728 & 95.20 & 103.45 & 95.61 \\
\hline 2 & Tyrosine & 100 & 4.28 & 342 & 75.50 & 32.29 & 81.10 \\
\hline 3 & L-Arginine & 100 & 3.35 & 52 & 7.00 & 2.65 & 24.20 \\
\hline 4 & Iso-Leucine & 100 & 2.33 & 125 & 12.80 & 6.98 & 37.60 \\
\hline 5 & Serine & 100 & 2.40 & 23 & 10.90 & 2.94 & 58.60 \\
\hline 6 & Glutamine & 100 & 37.50 & 1180 & 33.90 & 8.62 & 33.20 \\
\hline 7 & Lactic Acid & 100 & 15.21 & 432 & 30.00 & 7.21 & 31.00 \\
\hline 8 & Methionine & 100 & 20.12 & 559 & 21.80 & 13.57 & 26.50 \\
\hline 9 & Histidine & 100 & 17.48 & 2384 & 34.50 & 17.71 & 21.60 \\
\hline 10 & Valine & 100 & 2.57 & 181 & 76.30 & 25.45 & 30.53 \\
\hline 11 & Threonine & 100 & 32.12 & 68 & 85.00 & 30.40 & 16.10 \\
\hline
\end{tabular}

\section{Separation of different amino acids through HPLC}

The current HPLC based method used for the determination of amino acid gave clear separation of different amino acids from the yeast cream. The sequence of elution of all the test amino acids from both samples were similar to standards Different amino acids were determined in varying, from low to high, amount thus proving the sensitivity of the method.

\section{Amino acid profiling of S-samples}

The opted HPLC method not only separated the different amino acids from Ssamples very well (Figure 1) but also showed that different essential amino acids were present in yeast cream in very reasonable amount (Figure 2). Despite a concerted effort, serine and glutamine could not be determined in yeast cream produced from Saf Instant yeast (S-samples). Although, such amino acids could not be detected through HPLC, however, presence of these amino acids in very minute quantity can not be ruled out, that may be due to below the detection limit of HPLC. The most abundant amino acid was iso-Leucine $(36 \%)$ followed by 


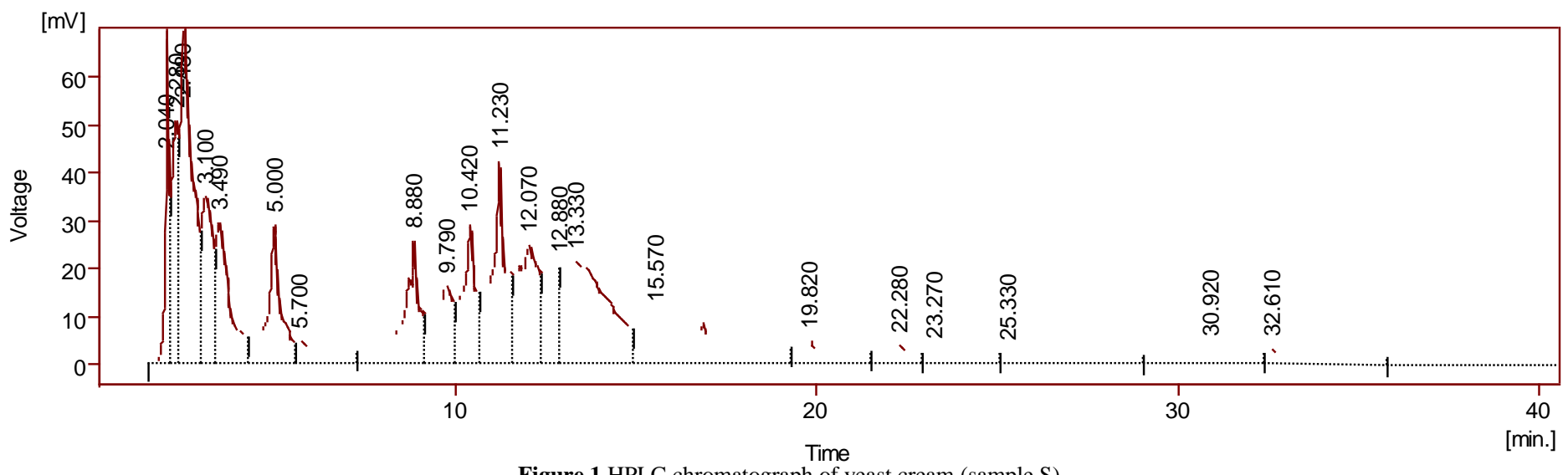

Figure 1 HPLC chromatograph of yeast cream (sample S)

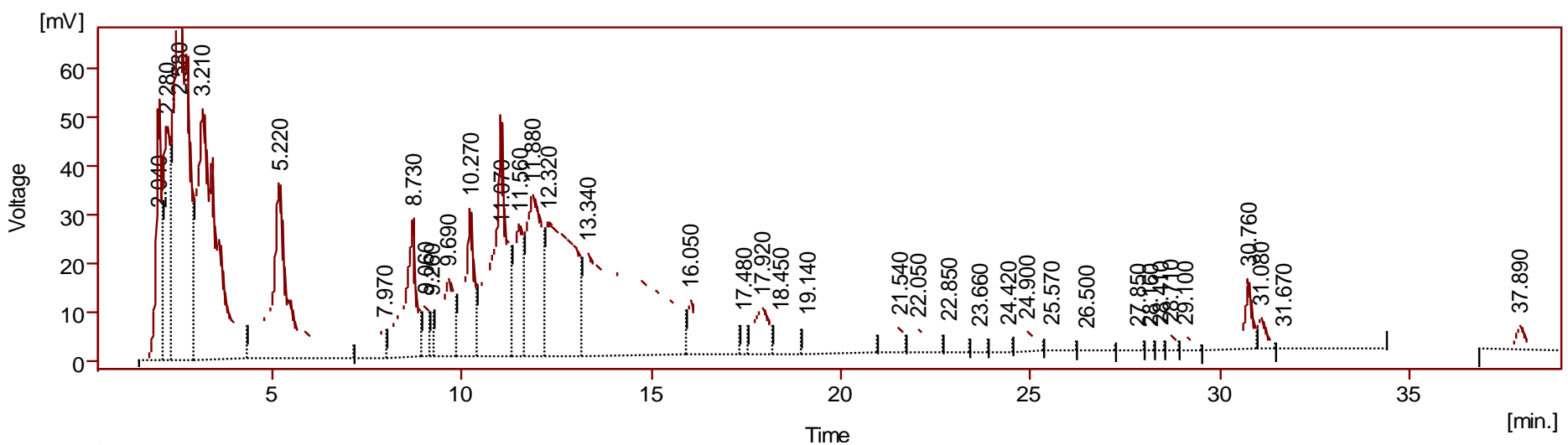

Figure 3 HPLC chromatograph showing separation of different amino acids from yeast cream T sample

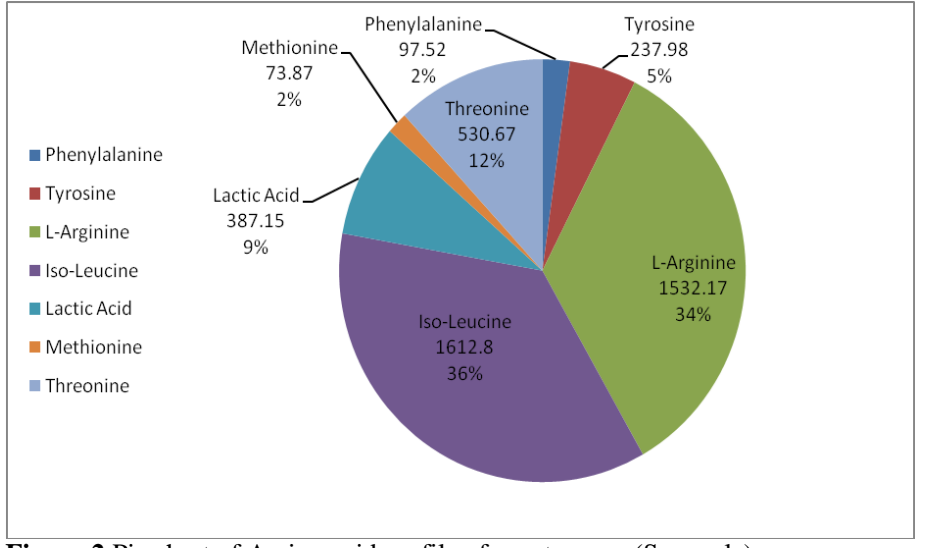

Figure 2 Pie chart of Amino acid profile of yeast cream (S sample)

\section{Amino acid profiling of T-samples}

Separation of different amino acids in T samples were also achieved through this methods and figure 3 is showing the chromatographic separation of different amino acids. Interestinlgy, amino acid profile of yeast cream samples "T" showed that amino acids, absent in S-samples, were found to be present in $\mathrm{T}$ samples (Figure 4).

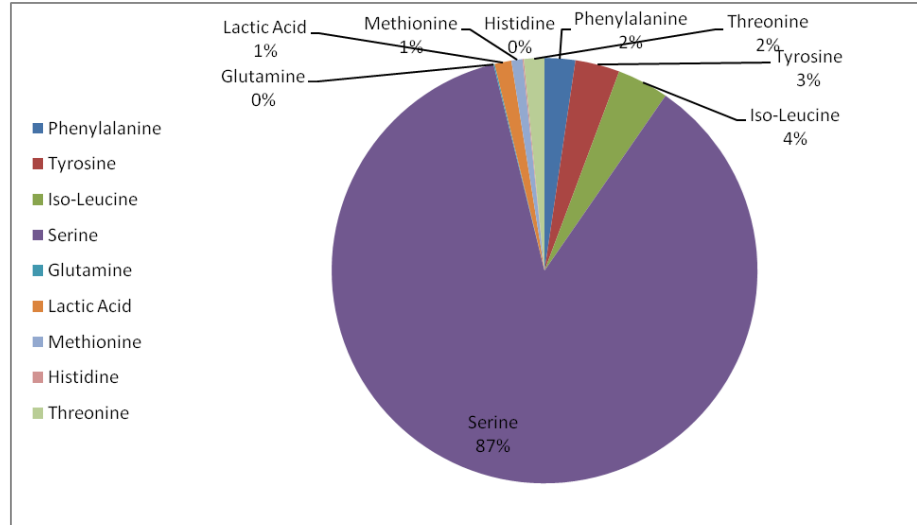

Figure 4 Pie chart of Amino acid profile of thermophilic yeast cream (Red)

Serine that could not be detected in S-samples was very high $(\sim 87 \%)$ in $\mathrm{T}$ samples. Similalry, glutamine percentage was found to be $4 \%$ in T-samples. Another, major exception was absence of arginine in these samples that rendered it good.However, other amino acid iso-Leucine $(4 \%)$, tyrosine $(3 \%)$, therionine $(2 \%)$, phenylalanine $(1 \%)$, methionine $(0.1 \%)$ and, glutamine were present in very low amount. While lactic acid was found to be $1 \%$ (Figure 4 ).

\section{Crude protein/nitrogen estimation and defating of dried yeast samples}

Before HPLC, the yeast samples were subjected to crude protein estimation through Kjeldhal method. This method gave an approximate idea about the percentage of protein. The results showed that concentration of crude protein was higher in T-samples $(9.42 \%)$ as compared to S-samples $(7.31 \%)$. However, the quantity of fat was found to be almost same i.e $\sim 8 \%$ in both yeast samples.

\section{DISCUSSION}

The study described here was stimulated by the increasing demand of protein (as feed) in poultry industry. Such increase in demand is being met from plant and animal sources on which human are dependent, thus, leading towards paucity of 
resources. SCP is defined as an alternative source of protein for food and feed which obtained from microbes especially from yeast, bacteria and algae. SCP produced by the yeast has the potential to be opted because of high bioactive compound such as proteins, essential amino acids, vitamins, polysaccharides, lipids, organic acids, phospholipids, polyamines, astaxanthines, $\beta$-carotene, trehalose, glutathione, superoxide dismutase, chitinase, amylase and phytase (Hotmaida, 2013). High level of SCP have been achieved through yeast at National research council (NRC) USA and overall crude protein levels were found to be 23, 20, and $18 \%$ for starter, grower and finisher phases respectively (National Research Council, 1994). Although, various independent studies have evaluated the SCP ingredients produced by yeast but no such studies have looked at its potential use in poultry industry.

Methionine is considered as an important limiting amino acids in broiler diets which play important role in growth as well as for humoral and cellular immunity of chickens which infected with Newcastle virus (Tsiagbe, 1987). Gbmegia $\boldsymbol{e}$ al.,(2012) showed that $0.34 \%$ methonine and $0.75 \%$ play an important for the growth of birds.Amino acid profiling of collected yeast cream showed the presence of methionine in both samples, however, relatively abundance of methionine is high (2\%) in S-samples (Fig. 1) while, the percentage of methionine was $1 \%$ in T-samples (Fig. 2) (Gbmegia,2012). These findings showed that thermophilic yeast cream have optimum quantity as afeedstock for growing birds

The percentage value of arginine was quite high in S-samples (34\%, Fig. 1), even quite higher than recommended quantity $(1-1.44 \%)$ of arginine in poultry diet (Lewis, 1963), while arginine could not be detected in samples-T. The arginine has previously been shown to be essential for improving egg production, egg weight as well as improving meat quality by modulating lipid metabolism, which in turn reduces the body fat accumulation and increases the antioxidant defense, furthermore, L-arginine has the ability to alleviate stress, normalise growth performance, reduces mortality under low ambient temperatures, attenuates the adverse effects of heat stress and high stocking density, activates the immune system and enhances its responses to different common diseases in poultry farms (Fouad, 2012). Although, yeast cream is highly enriched with arginine, however, substantiate amount of arginine should be adjusted if yeast cream is opted as feed source.

Threonine is a major component of plasma $\gamma$-globulin in animals and it found to $12 \%$ in S-samples (Fig. 1), while merely $2 \%$ threonine was found to be present in T-samples (Fig. 2). Threonine often appears as the third limiting amino acids, it dietry intake influences the components of the immune system $(\mathbf{L i}, \mathbf{2 0 0 7})$ although no clear report of a special need of threonine for immunity in poultry is present (Kidd, 2004). L-threonine is the necessary complement of L-lysine for which it optimizes the use by animals for body protein deposition and weigh gain. Moreover, L-threonine plays an important role in maintenance processes and more particularly in digestion. Khan et al., (2006) experimentally proved that digestible threonine level of $0.73 \%$ helps in gaining weight, feed consumptionand improves breast meat yield (Khan, 2006). So, again our results are showing that yeast cream produced by thermophilic strain (T-samples) has optimum level of threonine (Fig. 2), hence can be used in poultry feed.

Mehri et al., (2012) worked out the ideal ratios for both methionine and threonine to lysine, of Ross x Ross 308 male broiler chicks, from day 3 to day 16 Response surface methodology was employed using a central composite design. Body weight gain was maximized when Lysine was $1.12 \%$ and Methionine was $0.54 \%$, corresponding to a Methionine/Lysine ratio of 48 . Similar optimum requirements were noted for feed conversion with Lysine at $1.13 \%$ and Methionine at $0.53 \%$, corresponding to ideal ratios for Methionine/Lysine of 47 . The S-sample showed methionine and threonine in same concentration i.e 2\% (Fig. 1), while T-sample contain methonine 1\% and threonine 2\% (Fig. 2), which is almost similar ratio which is given by Mehri et al.,(2012). Branched-chain amino acid (BCAA, Valine, Isoleucine and Leucine) have been demonstrated vital for the development of immune organs, whereas it appears difficult to dissociate the specific effect of each BCAA ( $\mathbf{L i}, \mathbf{2 0 0 7}$; Kidd, 2004). The lowest Isoleucine:Lysine ratio (0.73:1) was sufficient to ensure satisfactory performance of birds, corresponding to the consumption of $534 \mathrm{mg}$ of isoleucine and $731 \mathrm{mg}$ of lysine/day (Heloisa, 2012). No differences were observed in the performance of hens over a wide range of dietary Isoleucine concentrations, but it can be inferred that the lower isoleucine:lysine ratio $(0.73: 1)$, can provide satisfactory performance of laying hens (Etienne, 2011). Current results showed that valine and leucine are absent in both Saf instant and extromophile yeast samples. Neverthless, isoleucine is present in higher quantity in S-samples 36\% $(1.6 \mathrm{mg} / \mathrm{mL})$, while in T-samples contain desired level of isoluecine which is about $4 \%(0.4 \mathrm{mg} / \mathrm{mL})$. Previous results showed that the broiler weight gain and feed conversion improved when isoleucine was supplemented to the lowest dietary isoleucine level fed. Supplementation with equal amounts of arginine did not alleviate the dietary isoleucine limitation, thus validating the essentiality and marginality of isoleucine in practical corn-soybean meal diets when at least $2 \%$ of meat-and-bone meal is present in diet formulation (Corzo, 2008). The isoluecine level present in S-samples is 36\% (Fig. 1), which is much higher than recommended levels while, in T-sample the level of isoleucine level is $4 \%$ which is near to recommended level (Fig. 2).
Vegetable protein is not a complete source of protein for Layer's feed. The low amount of protein retards the growth of birds. When the protein level exceeded from optimum level, it will undergo domination which converted protein into uric acid and removed as a fecal nitrogen and cause environmental pollution. On the other hand, in dominating process bird's loses more energy as compared to other process of the body. It is suggested that methionine $0.34 \%$ is optimum for growth of poultry (Gbmegia, 2012). Kalinowski et al., 2012 reported that the total methionine requirement in 0 to 3 week old broiler chicks was $0.50 \%$, regardless as to whether they were slow or fast feathering strains (Kalinowski, 2003). However, it was noted that the cysteine requirement was $0.39 \%$ for slowfeathering males versus $0.44 \%$ of fast-feathering males. Nutri-genomics study revealed that tryptophan is helpful increasing immune response and for bette health of broiler (Trevisil, 2012). High concentration of machine and intestinal infection can be decreased by increasing threonine in the diet (Star, 2012).Valine showed significant response when dietary protein is low in broiler feeds (Magdalena, 2013). Our results pinpointed that yeast cream produced by extremophile (T-samples) contains optimum quantity of threonine of $2 \%$ while, higher amount of threonine (12\%) was present in S-sample (Fig 1 and 2).

Teresa (2009) showed that fresh acid whey or lactic acid in the amount of $4 \mathrm{~cm}^{3} / \mathrm{L}$ $(4 \mathrm{~mL} / \mathrm{L})$ in poutry feed could effectively prevent the reduction in poultry production by decreasing the mortality risk in chickens as compared to chickens fed with a poor-quality diet (Teresa, 2009). However, a negative effect on broilers production was observed when acidified diet (containing both whey and lactic acid) was given in addition to acidified drinking water, so broiler producers should not use lactic acid or whey as drinking liquid if the chicken are being fed with acidified diet (Teresa, 2009). HPLC analysis of yeast cream showed that both T- and S-samples contain sufficient amount of lactic acid, thus can be adopted as feed source for broilers (Fig. 1 and 2). The high level of serine in amino acid anlaysis is one of the main problem for utilization of yeast cream as a source of feed so, one possible way to deal this sort of problem to add a enzyme serine dehdratase which deaminate the serine into pyruvate. In order to industrilizd and economized this process immobilized serine dehydratase is good option.

\section{CONCLUSION}

The overall study indicated that T-sample which is obtained from cream of Thermophilic yeast (Red) has optimum level of amino acids and lactic acid contents, thus it can be opted as a potential ingredient of poultry feed. Some amino acids are present in larger quantity in yeast cream, for example serine, such amino acids should be brings to optimum level to make yeast cream an excellent supplement for broilers. Although, alone yeast cream could not be used as a feed in poultry industry but can be mixed with other feed sources, thus a competition can be reduced for food inbetween human and brids. However, careful analysis and trials should be conducted on broilers before mixing it with other poultry ingredients. This study is a key step for utilization of waste of yeast cream of distillery as a broiler feed which is not being tried yet.

\section{Conflicts of Interest}

Authors declares no conflicts of interests.

\section{Authors' Contributions}

Zafar Iqbal and Zahid Anwar done statistical anlaysis and drafted manuscript Shoaib Ali and Mudassar Zafar done chemical analysis and conduct the research Munir Ahmad Sheikh supervised shoaib Ali, while, Muhmmad Khurshid and Muhammad Irshad coordinate in desingin and drafting the manuscript. The final version of manuscript was studied and approved by all authors.

\section{REFERENCES}

GADANHO, M., ALMEIDA, J.M.G.C.F., SAMPAIO J.P. 2003. Assessment of yeast diversity in a marine environment in the south of Portugal by microsatellite-primed PCR. Antonie van Leeuwenhoek., 84(3), 217-227. http://dx.doi.org/10.1023/a:1026038213195

STEWART, R. 1998. An Introduction to Brewing Science and Technology: Brewer's Yeast. The Institute of Brewing, London. 108-109. ISBN: 0900489138. WALKER, G.M. 1998. Yeast Physiology and Biotechnology. John Wiley and Sons, Chichester. 350-353.

ERTEN H.,TANGULER H. 2006. The production methods of yeast extract. Feed Info News Service. Fresh water fish species of Northern Nigeria. Academy Journal of Science, 41(6), 11-15.

STAM, H., Hoogland M., LAANE, C. 1998. Food flavours from yeast. Microbiology of Fermented Foods, 2, 505-542. http://dx.doi.org/10.1007/978-14613-0309-1_16

KHAN, M. L. 2001. Poultry feeds and nutrition. Kitabistan Publishing Co. 38-Urdu Bazar, Lahore. 
BUSTAMANTE, M. A., MORAL, R., PAREDES, C., ESPINOSA, A.P. MORENO-CASELLES, J., PEREZ-MURCIA, M.D. 2008. Agrochemical characterization of the solid byproducts and residues from the winery and distillery industry. Waste $28: 372-380$ http://dx.doi.org/10.1016/i.wasman.2007.01.013

SHARIF, M., SHAHZAD M.A.S., REHMAN S., KHAN R., ALI K.M.L., KHAN, K. 2012. Nutritional Evaluation of Distillery Sludge and Its Effect as a Substitute of Canola Meal on Performance of Broiler Chickens. AsianAustralasian Journal of Animal Sciences, 25(3),401-409. http://dx.doi.org/10.5713/ajas.2011.11279

ANNE, F. 2008. Organic Poultry Productionin the United States. A Publication of ATTRA - National Sustainable Agriculture Information Service, 2008. 1-16. ANONYMOUS, 2009. Amino acids focus at Adisseo seminar. World Poultry. Sept. 2 .

DIZ, M.S., CARVALHO A.O.R., RODRIGUES A.G., NEVES-FERREIRA M. DACUNHA E.W., ALVES, A.L., OKOROKOVA-FACANHA, M.A., OLIVEIRA, J., PERALES, O.L., MACHADO, G.V.M. 2006. Antimicrobia peptides from chili pepper seeds causes yeast plasma membrane permeabilization and inhibits the acidification of the medium by yeast cells. Biochimica et Biophysica Acta (BBA) - General Subjects, 1760(9),1323-1332. http://dx.doi.org/10.1016/j.bbagen.2006.04.010

BAIZE, J.C. 2000. Global soybean meal sampling and analysis activity. United Soybean Board contract\#0586 with John C. Baize, Falls Church, Virginia. 2000.

KANURI, A.B., RAVIKANTH, M.J.K., THAKUR, A., MAINI, S. 2014 Comparative efficacy of herbal and synthetic amino acids for growth performance and hepatoprotective action in broiler chickens. International Journal of Biomedical and Advance Research,

05(01), 14-18. http://dx.doi.org/10.7439/ijbar.v5i1.589

SAIMA, M., AKHTER, M.Z.U.K., ANJUM, M.I., AHMED, S., RIZWAN, M., IJAZ, M., 2008. Investigation On The Availability Of Amino Acids From Different Animal Protein Sources In Golden Cockerels. Journal of Animal and Plant Sciences, 18(2-3),53-55

TERESA, M., KRZYSZTOF, P., KRZYSZTOF, K., KRZYSZTOF, B. PAULIUS, M. 2009. Whey and lactic acid in broiler chickens nutrition. Veterinary medicine and zootechnics, 47:69.

SUDHA, K.R., KARTHIKEYAN, S., 2005. Distillery Yeast Sludge (DYS) as an Alternative Feed Resource in Poultry. International Journal of Poultry Science,4(10), 787-789. http://dx.doi.org/10.3923/ijps.2005.787.789

ECONOMIC SURVEY OF PAKISTAN, 2013-2014. Govt. of Pakistan. Finance Division Economic Advisor's Wing, Islamabad.

ESONU, B.O., OGBONNA, U.D., ANYANWU, G.A., EMENALOM, O.O., UCHEGBU, M.C., ETUK, E.B., UDEDIBIE, A.B.I. 2006. Evaluation of performance, organ characteristics and economic analysis of broiler finisher fed dried rumen digesta. Int. J. Poultry Science, 5:1116-1118 http://dx.doi.org/10.3923/ijps.2006.1116.1118

ASSOCIATION OF OFFICIAL ANALYTICAL CHEMISTS (A.O.A.C.) 1990 Official methods of analysis. In:Association of official Analytical Chemists. $\left(15^{\text {th }}\right.$ Edition). Arlington Virginia, USA

SKOTTY, D. R., WON-YONG, L., NIEMAN,T.A.,1996. Determination of dansyl amino acids and oxalate by HPLC with electrogenerated chemiluminescence detection using tris(2,2'-bipyridyl)ruthenium(ii) in the mobile phase. Analytical Chemistry,68(9),1530-1535. http://dx.doi.org/10.1021/ac951087n

HOTMAIDA, S., TRI, A., OSFAR, S. 2013. The amino acid profile of yeasts from ketchup factory waste as a candidate of single cell protein (SCP) International Journal of Biosciences. 3(9), 36-43. http://dx.doi.org/10.12692/ijb/3.9.36-43

NATIONAL RESEARCH COUNCIL, 1994. NutrientRequirements of Poultry. 9 th rev. ed. National Academy Press, Washington, D.C.1994

TSIAGBE, V.K., COOK, M.E., HARPER, A.E., SUNDE, M.L. 1987. Enhanced immune responses in broiler chicks fed methionine-supplemented diets. Poultry Science, 66(7),1147-1154. http://dx.doi.org/10.3382/ps.0661147

GBMEGIA, O.A., SULAIMAN, A.A., FOLUKE, A.A. 2012. The effect of varied dietary crude protein levels with balanced amino acids on performance and egg quality characteristics of layers at first laying phase. Food and Nutrition Sciences, 3,526-529. http://dx.doi.org/10.4236/fns.2012.34074

LEWIS, D., SMITH, G.H., PAYNE, C.G. 1963. Dietary requirement for arginine. Arginine in poultry nutrition. British Journal of Nutrition, 17(01),415. http://dx.doi.org/10.1079/bjn19630045

FOUAD, A.M., EL-SENOUSEY, H.K., YANG, X.J., YAO, J.H. 2012. Role of dietary L-arginine in poultry production. International Journal of Poultry Science. 11,718-729. http://dx.doi.org/10.3923/ijps.2012.718.729

LI, P., YIN, Y-L., KIM, S.W., WU, G. 2007. Amino acids and immune function. British Journal of Nutrition, 98(2),237-252. http://dx.doi.org/10.1017/s000711450769936x

KIDD, M.T. 2004. Nutritional modulation of immune function in broilers. Poultry Science, 83(4),650-657. http://dx.doi.org/10.1093/ps/83.4.650

KHAN, A.R., NAWAZ, H., ZAHOOR, I. 2006. Effect of different levels of digestible threonine on growth performance of broiler chicks. Journal of Animal and Plant Sciences, 16,1-2. http://dx.doi.org/10.2141/jpsa.43.388
MEHRI, A., DAVARPANAH, A., MIRZAEI, H.R. 2012. Estimation of ideal ratios of methionine and threonine to lysine in starting broiler chicks using response surface methodology. Poultry Science, 91(3),771-777. http://dx.doi.org/10.3382/ps.2011-01818

HELOISA, H.D.C.M., PAULO, C.G., TATIANA, C.D.R., JUAREZ, L.D., RODRIGO, L.D.A., ALLAN, R.T., BRUNO, R.D.C., GABRIEL, D.S.V. 2012 Determination of digestible isoleucine:lysine ratio in diets for laying hens aged 42-58 weeks Revista Brasileira de Zootecnia 41(5),13131317. http://dx.doi.org/10.1590/s1516-35982012000500032

ETIENNE, C., AJINOMOTO, E. J., 2011. (Lohmann AnimalHealth GmbH \& Co. KG) valine and Isoleucine. The next limiting amino acids inbroiler diets. 46,59 .

CORZO, A., DOZIER, W.A., KIDD, M.T., HOEHLER, D., 2008. Impact of Dietary Isoleucine Statuson Heavy-Broiler Production. International Journal of Poultry Science. 7(6),526-529. http://dx.doi.org/10.3923/ijps.2008.526.529

KALINOWSKI, A., MORAN, E.T., WYATT, C., 2003. Methionine and cystine requirements of slow-and fast-feathering male broilers from zero to three weeks of age. Poultry Science, 82(9),1423-1427. http://dx.doi.org/10.1093/ps/82.9.1423 TREVISIL, P., CORRENT, E., MESSORI, S., FORMICA, S., PRIORI, D., BOSI, P. 2012. Supplementary tryptophan down regulates the expression of genes induced by the gutmicrobiota in healthy weaned pigs susceptible to enterotoxigenic Escherichia coli F4. Livestock Science, 147(1-3), 96-103. http://dx.doi.org/10.1016/j.livsci.2012.04.008

STAR, L., ROVERS, M., CORRENT, E., VANDER, K.J.D. 2012. Threonine requirement of broiler chickensduring subclinical intestinal Clostridium infection. Poultry Science, 91(3):643-652. http://dx.doi.org/10.3382/ps.2011-01923

MAGDALENA, L., LEITGEB, R., BARTELT, J., CORRENT, E., SCHEDLE, K. 2013. Impact of an increasing true digestible (TD)valine to lysine ratio in a protein reduced dieton the performance of broiler chicks. Proceeding of the Society of Nutrition and Physiology. 22, and AEL's trial report 12AT02. 